\title{
Gambaran pengetahuan stroke pada penderita dan keluarga di RSUP Prof. Dr. R. D. Kandou Manado
}

\author{
${ }^{1}$ Giovanni R. Semet \\ ${ }^{2}$ Mieke A. H. N. Kembuan \\ ${ }^{3}$ Winifred Karema
}

\author{
${ }^{1}$ Kandidat Skripsi Fakultas Kedokteran Universitas Sam Ratulangi Maando \\ ${ }^{2}$ Bagian/SMF Neurologi Fakultas Kedokteran Universitas Sam Ratulangi Manado \\ Email: giosemet@gmail.com
}

\begin{abstract}
Stroke or circulatory disorders of the brain is a major problem in the field of neurology. Not only the number of events is increasing, but also the possibility of sequel will disturb for a long time. During this time, most people only assume that strokes only occur in adult or old people. In fact, stroke can also occur in adolescents. In Indonesia, it is estimated that each year 500,000 people are affected by stroke, about $2.5 \%$ or 125,000 people died, and the rest have mild or severe disabilities. Risk factors for stroke include hypertension, atherosclerosis, high level of cholesterol, heart problems, diabetes, family history of stroke, smoking, aging, unhealthy food, alcohol, less activitiy/exercise, oral contraceptives, obesity, and stress. This was a descriptive study conducted with survey method at Prof. Dr. R. D. Kandou Hospital Manado from November to December 2015. Conclusion: Most respondents consisted of 19 patients and 27 relatives of patients had high level of knowledge of the stroke. Knowledge of stroke patients was higher than their relatives.
\end{abstract}

Keywords: stroke, knowledge of stroke

\begin{abstract}
Abstrak: Stroke atau gangguan peredaran darah otak merupakan problem utama dibidang neurologi. Bukan hanya angka kejadiannya yang makin meningkat, tapi juga kemungkinan tersisanya sekuel yang menganggu untuk waktu yang lama. Pendapat umum menganggap bahwa stroke hanya dialami oleh mereka pada usia dewasa atau tua. Padahal stroke juga bisa terjadi pada remaja. Di Indonesia diperkirakan setiap tahunnya terjadi 500.000 penduduk terkena serangan stroke, sekitar 2,5\% atau 125.000 orang meninggal, dan sisanya cacat ringan maupun berat. Faktor risiko terjadinya stroke antara lain hipertensi, kolestrol anteriosklerosis, gangguan jantung, DM, riwayat stroke dalam keluarga, merokok, usia, makanan tidak sehat, alcohol, kurang berolaraga, kontrasepsi oral, obese dan stress. Jenis penelitian ialah deskriptif yang dilaksanakan dengan metode survei di RSUP Prof. Dr. R. D. Kandou Manado periode November-Desember 2015. Simpulan: Dari 19 pasien dan 27 keluarga pasien memiliki tingkat pengetahuan yang tinggi terhadap stroke. pengetahuan pada pasien stroke lebih tinggi dari pada keluarga.
\end{abstract}

Kata kunci: stroke, pengetahuan mengenai stroke

Stroke adalah cedera vaskuler akut pada otak. Dengan kata lain stroke adalah suatu cedera mendadak dan berat pada pembuluh-pembuluh darah otak. Cedera dapat disebabkan oleh sumbatan bekuan darah, pemyempitan pembuluh darah, sumbatan dan penyempitan, atau pecahnya pembuluh darah. Semua ini menyebabkan kurangnya pasokan darah yang memadai. ${ }^{1}$

Stroke merupakan suatu gejala klinis yang pada awal timbulnya terjadi mendadak, progresif cepat, berupa deficit neuorologis yang berlangsung 24 jam atau lebih yang dapat menimbulkan kematian 
dan hanya disebabkan oleh gangguan peredaran darah ke otak non traumatik. ${ }^{2}$

Data world health organization (WHO) tahun 2005 menyebutkan, $10 \%$ kematian di dunia disebabkan oleh stroke. Stroke merupakan kegawatan neurologis yang serius dan menduduki peringkatan yang tinggi sebagai penyebab kematian.,

Insiden di Asia berkisar 182-342 per 100.000 penduduk. Hasil rikerdas tahun 2007 menyebutkan stroke merupakan penyebab kematian terbanyak di Indonesia dengan presentasi $15,4 \%$ diikuti dengan hipertensi dan penyakit jantung. Di RSU Prof. Kandou Manado selama tahun 2009 tercatat 434 pasien stroke rawat inap dari total 10.566 pasien $^{5}$

Otak mempunyai kecepatan metabolisme yang tinggi, dengan berat hanya $2 \%$ dari berat badan, menggunakan $20 \%$ oksigen total dari $20 \%$ darah yang beredar. Pada keadaan oksigenasi cukup terjadi metabolism aerobic dari $1 \mathrm{~mol}$ glukosa dengan menghasilkan energy berupa $30 \mathrm{~mol}$ adenosin tripospat (ATP) yang diantaranya digunakan untuk mempertahankan pompa ion (NA-K pump), transport neurotransmitter (glutamate dll) kedalam sel, sintesis protein, lipid dan karbohidrat, serta transfer zat-zat dalam sel, sedang dalam keadaan iskemia seperti pada pasien stroke terjadi metabolism anaerobic dimana 1 mol glukosa menghasilkan energi ATP sehingga pompa ion (NA-K pump), transpor neurotransmitter kedalam sel, sintesis protein, lipid dan karbohidrat, serta transfer zat-zat dalam sel terganggu dan apabila keadaan ini tidak segera diatasi maka akan terjadi kematian sel. ${ }^{6}$

Stroke pada dasarnya terbagi menjadi berbagai jenis, Stroke iskemik: aliran darah ke otak terhenti karena penyumbatan, Stroke hemoragik: pembuluh darah pecah sehingga menghambat aliran darah normal dan darah merembes ke dalam suatu daerah di otak dan merusaknya, Stroke ringan
(Trancient ischemic attack/TIA), ${ }^{2,6,7}$

\section{METODE PENELITIAN}

Jenis penelitian ini ialah deskriptif yang dilaksanankan dengan metode survei menggunakan kuisioner. Penelitian ini dilaksanakan di RSUP Prof. Dr. R. D. Kandou Manado pada bulan November 2015 - Desember 2015. Populasi penelitian mencakup seluruh pasien stroke baik pria maupun wanita. Responden penelitian mencakup semua keluarga yang terkena stroke baik pria dan wanita yang datang di RSUP Prof. Dr. R. D. Kandou Manado selama bulan November 2015 - Desember 2015. Variabel penelitian yaitu pengetahuan pasien stroke dan keluarga bahaya stroke, pengertian, tanda dan gejala, faktor, pola hidup, dan upaya pencegahan

\section{HASIL PENELITIAN}

Dalam penelitian ini didapatkan 42 responden yang terdiri dari 19 pasien stroke dan 27 keluarga pasien. Dari 19 orang pasien terdapat 6 pria dan 13 wanita

Tabel 1. karateristik sampel penelitian

\begin{tabular}{lccc}
\hline & Pasien & Keluarga & N \\
\hline Jenis kelamin & & & \\
Pria & 6 & 12 & 18 \\
Wanita & 13 & 15 & 28 \\
Jumlah & 19 & 27 & 46 \\
\hline Usia (tahun) & & & \\
15-25 & 0 & 9 & 9 \\
26-45 & 0 & 8 & 8 \\
46-65 & 19 & 10 & 29 \\
Jumlah & 19 & 27 & 46 \\
\hline Pendidikan & & & \\
terakhir & & & \\
SMA/SMK & 15 & 18 & 33 \\
D3 & 1 & 2 & 3 \\
S1 & 3 & 7 & 10 \\
Jumlah & 19 & 27 & 46 \\
\hline & & & \\
\hline
\end{tabular}


Tabel 2. Sebelumnya mengetahui penyakit stroke

\begin{tabular}{lccc}
\hline Jawaban & Pasien & Keluarga & N \\
\hline A.Ya & 4 & 14 & 18 \\
B.Tidak & 15 & 13 & 28 \\
Jumlah & 19 & 27 & 46 \\
\hline Jawaban & Pasien & Keluarga & $\mathbf{N}$ \\
A.Ya & 4 & 14 & 18 \\
B.Tidak & 15 & 13 & 28 \\
Jumlah & 19 & 27 & 46 \\
\hline Jawaban & Pasien & Keluarga & $\mathbf{N}$ \\
A.Ya & 4 & 14 & 18 \\
B.Tidak & 15 & 13 & 28 \\
Jumlah & 19 & 27 & 46 \\
\hline Jawaban & Pasien & Keluarga & $\mathbf{N}$ \\
A.Ya & 4 & 14 & 18 \\
B.Tidak & 15 & 13 & 28 \\
\hline
\end{tabular}

Tabel 3. pengetahuan stroke di dapatkan

\begin{tabular}{llll}
\hline Jawaban & Pasien & Keluarga & N \\
\hline A.media & 2 & 9 & 11 \\
B.tenaga medis & 14 & 11 & 25 \\
C.Internet & 3 & 7 & 10 \\
Jumlah & 19 & 27 & 46 \\
\hline
\end{tabular}

Tabel 4. Penyakit yang paling berbahaya

\begin{tabular}{llll}
\hline Jawaban & Pasien & Keluarga & N \\
\hline A.Stroke & 16 & 17 & 0 \\
B.Usus Buntu & 3 & 2 & 8 \\
C.Diabetes & 0 & 8 & 38 \\
Jumlah & 19 & 27 & 46 \\
\hline
\end{tabular}

Tabel 5. Penyakit yang menyebabkan kerusakan otak

\begin{tabular}{lccc}
\hline Jawaban & Pasien & Keluarga & Total \\
\hline A.Gastritis & 0 & 0 & 0 \\
B.Gagal jantung & 3 & 6 & 9 \\
C.Stroke & 12 & 21 & 33 \\
Jumlah & 15 & 27 & 42 \\
\hline
\end{tabular}

Tabel 6. Penyumbatan pembuluh darah otak

\begin{tabular}{lccc}
\hline Jawaban & Pasien & Keluarga & N \\
\hline A. Aliran darah di otak lancar & 0 & 0 & 0 \\
B. Aliran darah di otak tidak lancar & 15 & 11 & 26 \\
C. Aliran darah di organ lain tidak lancar & 4 & 16 & 20 \\
Jumlah & 19 & 27 & 46 \\
\hline
\end{tabular}

Tabel 7. Proses terjadinya stroke

\begin{tabular}{lccc}
\hline jawaban & Pasien & keluarga & Total \\
\hline $\begin{array}{l}\text { A.masuk benda asing dalam pembuluh } \\
\text { darah otak,dan tidak terjadi sumbatan }\end{array}$ & 2 & 4 & 6 \\
$\begin{array}{l}\text { B.masuk sari-sari makanan dan oksigen } \\
\text { yang dibawah oleh pembuluh darah ke }\end{array}$ & & & \\
$\quad$ otak & 1 & 5 & 6 \\
C.tersumbatnya pembuluh darah otak & 12 & 18 & 30 \\
Jumlah & 15 & 27 & 46 \\
\hline
\end{tabular}

Tabel 8. Penyakit yang bisa menjadi penyebab stroke

\begin{tabular}{lccc}
\hline Jawaban & Pasien & Keluarga & Total \\
\hline A.Hepatitis & 0 & 3 & 3 \\
B.Hipertensi & 15 & 22 & 41 \\
C.Reumatik & 0 & 2 & 2 \\
Jumlah & 15 & 27 & 46 \\
\hline
\end{tabular}


Tabel 9. Kebiasaaan yang dapat menyebabkan timbulnya penyakit stroke

\begin{tabular}{lccc}
\hline Jawaban & Pasien & Keluarga & Total \\
\hline A.Sering mengonsumsi makanan ringan & 2 & 5 & 7 \\
B.Sering mengomsumsi makanan & & & \\
$\quad$ berlemak serta alkohol & 17 & 27 & 39 \\
C.Sering mengonsumsi makanan berserat & 0 & 0 & 0 \\
Jumlah & 15 & 27 & 46 \\
\hline
\end{tabular}

Tabel 10. Tanda dan gejala stroke

\begin{tabular}{llll}
\hline Jawaban & Pasien & Keluarga & Total \\
\hline A.Pasien menjerit kesakitan & 4 & 8 & 12 \\
B.Mulut mencong & 15 & 19 & 34 \\
C.Adanya luka di bagian kepala & 0 & 0 & 0 \\
Jumlah & 19 & 27 & 46 \\
\hline
\end{tabular}

Tabel 11. Tanda lain yang disebabkan oleh penyakit stroke

\begin{tabular}{llll}
\hline Jawaban & Pasien & Keluarga & Total \\
\hline A.Lumpuh separuh badan & 14 & 19 & 33 \\
B.Tubuh menjadi pegal-pegal & 5 & 8 & 13 \\
C.Tidak ada tanda dan gejala & 0 & 0 & 0 \\
Jumlah & 19 & 27 & 46 \\
\hline
\end{tabular}

Tabel 12. Menurut anda, apakah yang menjadi tujuan dari rehabilitasi pasca stroke

\begin{tabular}{llll}
\hline Jawaban & Pasien & Keluarga & Total \\
\hline A.Untuk kesembuhan pasien & 3 & 6 & 9 \\
B.Untuk mengurangi kecacatan & 5 & 6 & 11 \\
C.Untuk memperbaiki fungsi tubuh yang & & & \\
terganggu, melatih keterampilan yang masih & & & \\
tersisa pada penderita sesuai dengan & & & \\
kemampuannya. & 11 & 15 & 24 \\
Jumlah & 15 & 27 & 46 \\
\hline
\end{tabular}

Tabel 13. Fungsi terapi biacara

\begin{tabular}{lccc}
\hline Jawaban & Pasien & keluarga & Total \\
\hline A.Supaya penderita mampu menggunakan kata-kata & 5 & 12 & 17 \\
$\begin{array}{l}\text { B.Meningkatkan kemampuan berkomunikasi bagi } \\
\text { penderita dan untuk mengurangi tingkat depresi }\end{array}$ & & & \\
penderita & 14 & 15 & 28 \\
Jumlah jawaban & 19 & 27 & 46 \\
\hline
\end{tabular}

Tabel 15. Menurut anda, apakah semua pasien penderita pasca stroke melakukan rehabilitasi yang sama

\begin{tabular}{lccc}
\hline Jawaban & Pasien & Keluarga & Total \\
\hline A.Ya & 8 & 9 & 17 \\
B.Tidak & 11 & 18 & 29 \\
Jumlah & 19 & 27 & 46 \\
\hline
\end{tabular}


Tabel 15. Menurut anda, kenapa setiap penderita pasca stroke tidak mendapatkan jenis rehabilitasi yang sama

\begin{tabular}{lccc}
\hline Jawaban & Pasien & Keluarga & Total \\
\hline A.Kuat lemahnya fisik penderita & 5 & 7 & 12 \\
B.Karena efek serangan stroke berbeda & & & \\
$\quad$ pada setiap orang & 14 & 20 & 34 \\
Jumlah & 15 & 27 & 46 \\
\hline
\end{tabular}

Tabel 16. Sampai kapan penderita harus melakukan rehabilitasi pasca stroke

\begin{tabular}{lccc}
\hline Jawaban & Pasien & Keluarga & N \\
\hline A. Sampai penderita mampu melakukan & 8 & 11 & 19 \\
$\quad$ kegiatan sendiri & 3 & 3 & 6 \\
B. Sampai 3 bulan sesudah serangan & 8 & 13 & 21 \\
C. Selama sisa hidup penderita pasca stroke & 19 & 27 & 46 \\
Jumlah & & & \\
\hline
\end{tabular}

\section{BAHASAN}

Pada penelitian ini didapatkan 42 responden yang terdiri dari 19 pasien stroke dan 27 keluarga pasien. Dari 19 orang pasien terdiri dari 6 pria dan 13 wanita, dengan tingkat pendidikan terakhir SMA/SMK 15 orang, D3 1 orang, S1 3 orang dengan rata-rata usia 57 tahun. Dari 27 responden keluarga pasien terdiri dari 12 pria dan 15 wanita dengan pendidikan terakhir 18 orang SMA/SMK, 2 orang D3, 7 orang S1 dengan rerata usia 32 tahun.

Dari hasil penelitian didapatkan sebagian besar responden memiliki pengetahuan yang baik tentang stroke karena semua responden berada di rumah sakit sehingga telah mendapatkan informasi dari tenaga medis. Hasil ini sesuai dengan penelitian di Jakarta yang menyebutkan bahwa $57,7 \%$ keluarga pasien stroke memiliki tingkat pengetahuan yang baik. Hasil penelitian tingkat pengetahuan pasien lebih tinggi dari keluarga. ${ }^{8}$ Juga hasil penelitian dari Universitas Indonesia menunjukan $55,4 \%$ responden memiliki pengetahuan yang baik tentang stroke dan berpengaruh pada tindakan rehabilitasi. ${ }^{24}$

Sebagian besar responden mendapatkan pengetahuan mereka tentang stroke dari tenaga medis. Responden sebelumnya kurang mendapatkan pengetahuan di lingkungan mereka sehingga ketika anggota keluarga mederita stroke tenaga medis yang memberikan pengetahuan tentang stroke.

Dari keseluruhan 90\% responden mengetahui bahwa hipertensi merupakan penyakit penyebab stroke. Hasil ini tidak sesuai dengan penelitian sebelumnya dimana kurang dari 50\% responden tidak mengetahui hipertensi sebagai penyebab stroke. Hal ini mungkin disebabkan karena responden pada penelitian sebelumnya merupakan pasien rawat jalan. ${ }^{8}$

Dari hasil penelitian $85 \%$ responden mengetahui bahwa mengomsusi makanan berlemak serta alkohol merupakan salah satu penyebab stroke. Hal ini sesuai dengan penelitian sebelumnya yang menyatakan lebih dari $50 \%$ responden mengetahui bahwa mengomsusmsi makanan berlemak serta alkohol merupakan salah satu penyebab stroke. ${ }^{8}$

Dari hasil penelitian $74 \%$ responden memiliki tingkat pengetahuan tanda dan gejala stroke yang baik.hasil ini sesuai dengan penelitian di Surabaya yang menyatakan $78,8 \%$ responden memiliki tingkat pengenalan gejala stroke yang baik. $^{8}$

Dari hasil penelitian $78 \%$ keluarga pasien mengetahui stroke merupakan penyakit yang menyebabkan kerusakan otak. Hasil ini sesuai dengan penelitian sebelumnya yang mengatakan dari hasil wawancara keluarga pasien mengenali 
stroke sebagai penyakit neurologis. ${ }^{9}$

Dari hasil penelitian sebagian besar responden memiliki tingkat pengetahuan rehabilitas stroke yang baik. Hal ini sesuai dengan hasil penelitian sebelumnya di dapatkan $92,1 \%$ responden yang memiliki pengetahuan rehabilitasi stroke yang baik. ${ }^{23}$ Hasil penelitian yang lain juga menyatakan bahwa sebagian besar keluarga pasien stroke memiliki pengetahuan yang cukup tentang perawatan pasca stroke. ${ }^{24}$

\section{SIMPULAN}

Dari hasil penelitian dapat disimpulkan bahwa responden yang terdiri dari 19 pasien dan 27 keluarga pasien memiliki tingkat pengetahuan yang tinggi mengenai stroke dan pengetahuan pasien stroke lebih tinggi dari pada keluarganya. Pengetahuan stroke dari sebagian besar keluarga pasien tergolong baik. Pada beberapa anggota keluarga dan anak remaja belum mempunyai pengetahuan baik mengenai stroke.

\section{DAFTAR PUSTAKA}

1. Soertidewi L, Misbach J. Epidemiologi stroke. In: Misbach J, Soertidewi L, Jannis J, editor. Stroke, aspek diagnosis, patofisiologi, manajemen. Jakarta: Balai Penerbit FKUI, 2011; p. 1-12,307.

2. Wiwit S. Stroke dan Penangananya (1st ed). Depok: Katahati, 2010; p. 28.
3. Japardi I. Patofiosiologi stroke infark akibat tromboemboli [Tesis]. Medan: Universitas Sumatera Utara; 2002.

4. Akmal NQ. Pola tekanan darah pada penderita stroke akut yang dirawat inap di bangsal neurologi RSU Prof. Kandou Manado periode 1 Januari 2009-31 Desember 2009 [Tesis]. Manado: Universitas Sam Ratulangi; 2010.

5. Hananta IPY, Freitag H. Deteksi Dini dan Pencegahan Hipertensi dan Stroke (1st ed). Yogyakarta: Media Pressindo; 2011; p. 52.

6. Ratnasari P. Hubungan antara tingkat ketergantungan activity daily living dengan depresi pada pasien stroke RSUP Tugerjo Semarang [Skirpsi]. Semarang: STIKES Telogorejo; 2012.

7. Hartini J. Hubungan tingkat pengetahuan dengan perilaku family caregiver dalam merawat penderita pasca stroke dirumah tahun 2012 [Skripsi]. Jakarta: UIN Syarif Hidayahtullah; 2013.

8. Sundah ABM. Pengetahuan masyarakat mengenai penanganan rehabilitasi medik pada penderita stroke di Kelurahan Pinaesaan Kecamatan Wenang Manado. eCl. 2014; 2(3):1-6

9. Sonatha B. Hubungan tingkat pengetahuan dengan sikap keluarga dalam pemberian perawatan pasien pasca stroke [Skripsi]. Depok: Universitas Indonesia; 2012. 